UNIVERSITY OF LONDON

INSTITUTE OF LATIN AMERICAN STUDIES

OCCASIONAL PAPERS No. 26

\title{
A Footnote to Borges Studies: A Study of the Footnotes
}

Evelyn Fishburn 



\title{
A FOOTNOTE TO BORGES STUDIES: A STUDY OF THE FOOTNOTES
}

\author{
Evelyn Fishburn
}


The Institute of Latin American Studies publishes as Occasional Papers selected seminar and conference papers and public lectures delivered at the Institute or by scholars associated with the work of the Institute.

Evelyn Fishburn was Professor of Latin American Literary Studies at University of North London, and is currently Visiting Professor at University College, London. Her books include Borges and Europe Revisited, Evelyn Fishburn (ed.) (ILAS, 1998); Short Fiction by Spanish American Women (1998); A Borges Dictionary (in collaboration with P. Hughes) (1990); and The Portrayal of Immigration in Nineteenth Century Argentine Literature (1845-1902) (1981). She has also published on Borges and England, humour, allusion, Cabbala, and the Jewish imaginary.

This paper was first presented as the valedictory lecture by Professor Fishburn in the Henry Thomas Room, University of North London, on 7 February 2001. She has recently been appointed Emeritus Professor of the University of North London.

Occasional Papers, New Series 1992ISSN 09536825

(C) Institute of Latin American Studies

University of London, 2002 


\section{A Footnote to Borges Studies: A Study of the Footnotes}

When the worldwide celebrations of 1999, the centenary of Borges's birth, came to an end it seemed as if nothing else could, or perhaps should, be said about the great writer, yet passionate interest in Borges continues. There was a well-founded fear that the persona, in the form of anecdotes about the literary figure, would come to eclipse the writer, a dichotomy that Borges anticipated with humour and subtlety in the famous page 'Borges and I': 'It's Borges, the other one, that things happen to.' ${ }^{1}$

Admittedly, hardly a day passes without some anecdotal reference to him in the Argentine press, and there is not an intellectual to be found who does not have a 'when I was with Borges' story - the present speaker is no exception - and judging by all those who claim they were present at his death, his must surely have been the most crowded death chamber in history, at least in literary history. But serious critical work continues to be produced: apart from some 14 biographies, the proceedings of the many symposia held in 1999, the gradual reissues of all his writings, and in the context of this paper I must mention the invaluable annotated edition of his complete works by Jean Pierre Bernès, and the growing importance of the journal dedicated solely to Borgesian studies, Variaciones Borges, all testify to this. ${ }^{2}$ Yet, paraphrasing a sentence by Borges on literature, 'The things that can be said about literature are always the same: what changes is the way of saying them,' I strongly suspect that the things that can be said about Borges are always the same: what changes is the way of saying them. This emphasis on the different routes of the journey rather than the arrival on which I have tended to concentrate in my work is entirely consistent with Borges's scepticism regarding anything novel and his own delight in the reworkings of a few basic ideas.

The key premise eloquently argued by so many critics in the past is that Borges's permanently open stories are in themselves examples of the 'total book' of literature, i.e. palimpsests in the sense of Genette's 'livre infini'. In revisiting this idea today, I should like to focus on an aspect that has not yet received due

1 In 'The Maker', Collected Fictions, translated by A. Hurley (New York, 1998), p. 323. All relevant references to Borges's work will be to this edition.

2 Borges, Oeuvres complètes, edited by Jean Pierre Bernès (Paris, vol. 1, 1993; vol. 2, 1999) and Variaciones Borges. Fournal of Philosophy, Semiotics and Literature (Aarhus). 
critical attention, namely, the footnotes, seeing these as imaginative devices that add to this livre by generating new readings. To adapt a metaphor used by William Rowe in a discussion on Borges, I see the footnotes as 'reading machines' that make holes in the text to redistribute it allowing for different configurations. ${ }^{3}$

$A$ Writer on the Edge is the title of one of the most important books of Borges criticism to have been published in the last few years: ${ }^{4}$ to approach Borges from the edges of the paper seems eminently appropriate given his avowed attraction for las orillas, the margins, and los orilleros, those living at the margins of society, the 'hoodlums' as he called them in his Edwardian English. It is also consistent with Borges's new prominence in courses dealing with borders and border crossings, at the University of North London (UNL) as well as in other universities.

But first, a few general remarks about the footnote, usually thought of as an additional piece of information, an adjunct, and almost by implication, of secondary importance, something that intrudes and interrupts. As once observed by Noël Coward, and often quoted since: 'having to read a footnote resembles having to go downstairs to answer the door while in the midst of making love'. ${ }^{5}$

The classic footnote serves to assure scientific exactness, and when used in the Humanities it is to establish a kind of parity with the Sciences: it underwrites the soundness of an argument with empirical support as it were. In short, it guarantees scholarship.

The traditional division between scholarly texts and the rest is often defined by the use of footnotes: an essay, conveying a personal argument is not annotated, whereas an argument with academic pretensions is, as students well know. ${ }^{6}$

But to what extent is a footnoted reference an objective tool or a rhetorical device? In recent years the footnote has become the subject as well as a method of scholarly commentary. ${ }^{7}$ For example, its complex trajectory has been mapped by Antony Grafton in his lucid, and witty, The Footnote: A Curious History. ${ }^{8}$ This is a title which cries out to be footnoted with the information that the French title of The Footnote: A Curious History is announced as Les origines trag-

3 'Reading Machine/Hole Machine', in 'How European is it?', Borges and Europe Revisited, edited by E. Fishburn (London, 1998), pp. 31-6.

4 Forge Luis Borges: A Writer on the Edge, edited by John King (London and New York, 1993).

5 B. Hilbert, 'Elegy for Excursus: The Descent of the Footnote', College English, vol. 51 (1989), p. 401; A. Grafton, The Footnote: A Curious History (Cambridge, MA, 1997)

6 There is now a small footnote industry in the form of a computer software, NotaBene, advertised as 'your bibliographic manager'. Another, put forward by the Department of Engineering of a leading university, sells its wares on the basis that: 'Footnotes make your documents look really fancy'.

7 Hilbert (1989). Ironically, Hilbert's study is published in a periodical that does not accept foothotes (College English).

8 See footnote 5 . 
iques de l'érudition: une histoire de la note en bas de page, the German translation reading Die tragishen ursprünge der deutschen fussnot (emphasis added; one can only marvel at the reasoning behind this transformation of the curious into the tragic, and the general into the German).

The power politics of annotation are often more subtle than is perhaps imagined. Grafton observes in a discussion related mainly to history texts that while a footnote can simply be informative and give the details of the place and publication of the source, if preceded by the 'deadly' c.f. (compare, Latin conferre) the footnote can act, and I quote loosely, as 'an encoded dagger stuck in the backs of the author's colleagues'. For while it may indicate an alternative opinion, there is a strong inference that it is one 'which is wrong'. It appears that Italian historians footnote everyone, so that not to footnote someone becomes a veiled, but recognised, slight. The Germans, on the other hand, only refer to older German sources: 'no need to admit the barbarians outside', conjectures Grafton. ${ }^{9}$

In pre-Web days, footnotes were a useful indicator of the range of library resources and particularly of economic and political bibliographical restrictions.

The Shorter Oxford Dictionary records the earliest use of the term 'footnote' as 1841, a somewhat late date considering its widespread presence in the eighteenth century and an interesting example, perhaps, of the belatedness of language, of the gap between reality and its linguistic codification.

Various dates have been mentioned ranging from the twelfth, the seventeenth, the eighteenth and the nineteenth centuries as marking the birth of the footnote, depending on one's understanding of the term. If we include annotations or commentaries, which is, after all, what footnotes are, these can be traced very far back, but footnotes proper, comments at the bottom, rather than the margins, of the page, appeared in the eighteenth century and were the result of a printing trend. One quarter of Gibbon's Decline and Fall (1776-88) is taken up with footnotes; the great historian was famous for the elegance, and often ironical personal observations, of his footnotes, which at once support and subvert the authority of his historical account. Eventually, again under printing pressures, the footnote was relegated to endnotes, which are cheaper to produce, but it seems that computer technology will allow, economically, the footnote to regain its rightful place, on the same page as the information it annotates. This last thought, regarding the placing of the footnote, leads me to ponder the basic question of what is the 'proper' relationship between a footnote and the text, or, put more polemically, what is the hierar-

9 Grafton (1997), pp. 10-11. 
chical relationship between commentary and text? The question is prompted by another: Which comes first, the footnote or the text? Also, where does a text stop and a footnote begin, or, as asked by one commentator: What exactly is 'hors d'oeuvre'?10

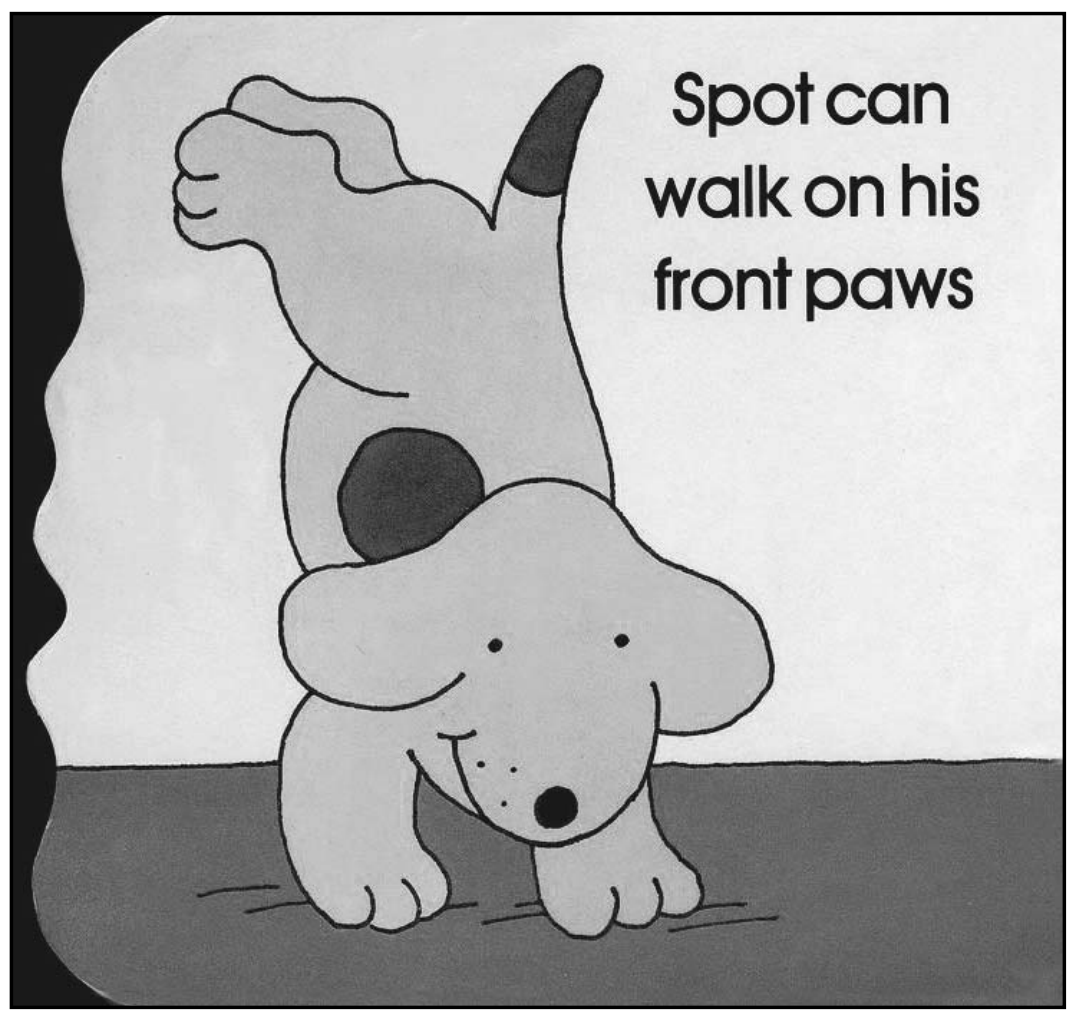

Spot can walk on his front paws. In this example: which is the 'text', which the gloss? Is the text an annotation to the picture? Or does the picture gloss the text? Can a hierarchy be established? It is not my intention to answer this question but to fantasise the possibilities that this illustration opens up for readings of annotated texts .

10 Stephen Barney (ed.), Annotation and its Texts (Oxford, 1991), p. vii. This is one in a list of basic questions that was sent out by the editor to his contributors, to establish the parameters for the symposium on annotations held at the University of California at Irvine in April 1988. 


\begin{tabular}{|c|c|c|c|}
\hline 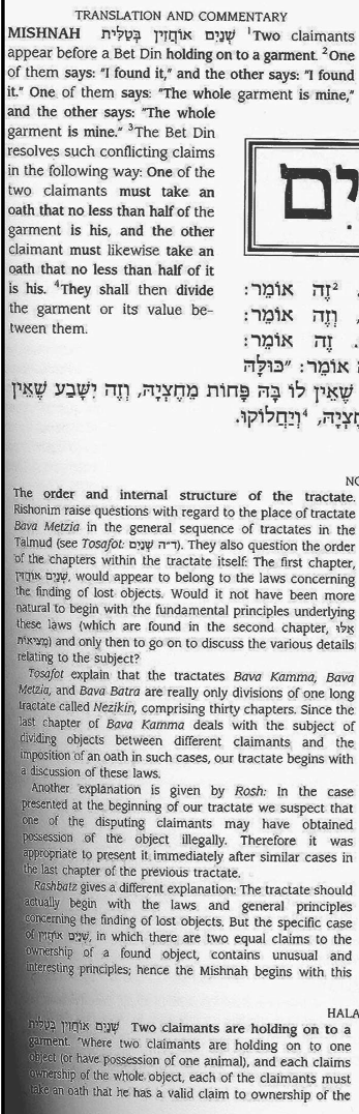 & \multicolumn{2}{|c|}{ 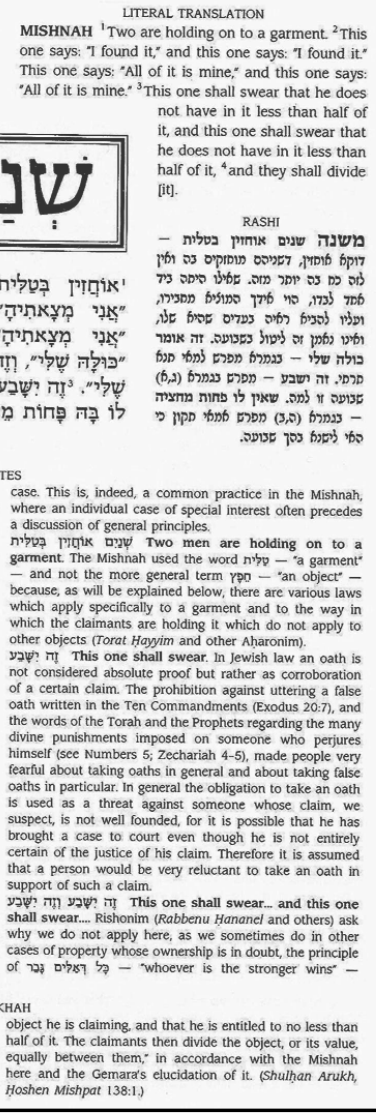 } & 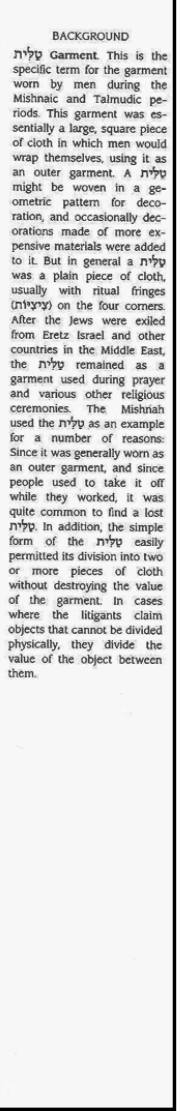 \\
\hline
\end{tabular}

This page from the Talmud, the Jewish compilation of oral teachings and their discussion, seems to present a clearly marked hierarchy between centre and margin. Yet how fixed is this relationship? The passage in Hebrew at the centre is THE TEXT, the codified Oral Law, and surrounding it are commentaries and interpretations; where does the real, the practical authority lie, in the central text or in the commentary which consists of explanations directing the reading of the text? The centre is no longer read without reference to the margins. We accede the central text from and through the commentaries; it is they that shape our understanding, direct our interpretation. We could say they have become the text.

Borges often expressed fascination with the Talmud, particularly for the interplay between a seemingly 'finite' or fixed text and its multi-layered readings, a theme that permeates his work. 
The issue of this relationship, focused on the boundaries of a text is playfully dealt with by Derrida in Glas (1974), a work which mimes and plays on the structuring of Rabbinical disquisitions. ${ }^{11}$

\begin{tabular}{|c|c|}
\hline $\begin{array}{l}\text { quoi du reste aujourd'hui, pour nous, ici, maintenant, } \\
\text { d’un Hegel? } \\
\text { Pour nous, ici, maintenant : voilà ce qu'on n'aura pu } \\
\text { désormais penser sans lui. } \\
\text { Pour nous, ici, maintenant : ces mots sont des cita- } \\
\text { tions, déjà, toujours, nous l'aurons appris de lui. }\end{array}$ & $\begin{array}{l}\text { "ce qui est resté d'un Rembrandt décbiré en petits } \\
\text { carrés bien réguliers, et foutu aux cbiottes " se divise } \\
\text { en deux. }\end{array}$ \\
\hline Qui, lui? & Comme le reste. \\
\hline 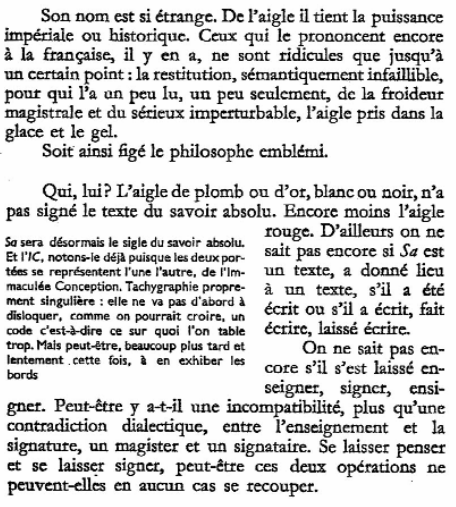 & $\begin{array}{l}\text { Deux colonnes intgales, disent-ils, dont chaque } \\
\text { - enveloppe ou gaine, incalculablement renverse, } \\
\text { retourne, remplace, remarque, recoupe l'autre. } \\
\text { L'incalculable de ce qui est resté se calcule, } \\
\text { ćlabore tous les coups, les tord ou les techafaude } \\
\text { en silence, vous vous epuiseriez plus vite à les } \\
\text { compter. Chaque petit carré se délimite, chaque } \\
\text { colonne s'enlève avec une impassible suffisance } \\
\text { ct pourtant l'élément de la contagion, la circulation } \\
\text { infinie de l'équivalence génćrale rapporte chaque } \\
\text { phrase, chaque mot, chaque moignon d'écriture } \\
\text { (par cxcmple " je m'éc... ") à chaque autre, dans } \\
\text { chaque colonne et d'une colonne à l'autre de ce } \\
\text { qui est resté infiniment calculable. }\end{array}$ \\
\hline 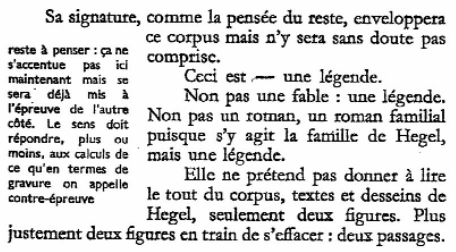 & $\begin{array}{l}\text { Il y a du reste, toujours, qui se recoupent, } \\
\text { deux fonctions. } \\
\text { L'une assure, garde, assimile, intériorise, } \\
\text { idéalise, relève la chute dans le monument. La } \\
\text { chutc s'y maintient, embaume et. momifie, monu- } \\
\text { mémorise, s'y nomme - tombe. Donc, mais } \\
\text { comme chute, s'y érige. }\end{array}$ \\
\hline
\end{tabular}

Note the parodic intention here: the centripetal, or unifying force of the mediaeval text has completely disappeared, making way to parallel texts whose relationship is to complicate meaning, not to elucidate it. The mediaeval text seeks a final truth, an original truth, whereas Derrida's text affirms the play of interpretation. Glas is about continuous deferral. It has no beginning, no end, no hierarchy: two texts (one a discussion of Hegel and another of Genet) are juxtaposed, each a selfcontained pillar, yet in some way annotating the other. Glas is a text commenting on itself commenting. ${ }^{12}$

11 See Geoffrey Hartman in Saving the Text (Baltimore, 1982). Hartman writes, 'Let no one mistake this nonbook: Glas is of the House of Galilee,' and refers to Derrida as Reb Derissa (p. 19). 12 Derrida deals with rabbinical interpretations in 'Edmond Jabès and the Question of the Book', Writing and Difference (London, 1978). See $f$ 3. 'The 'rabbinical' interpretation of interpretation is the one which seeks a final truth, which sees interpretation as an unfortunately necessary road back to an original truth. The 'poetical' interpretation of interpretation does not seek truth 
Commentary in fiction has, not surprisingly, concentrated more on subverting the unity of the text and destabilising, rather than affirming, the central narrative. The parodic mention of footnotes, in their older form of annotations, is, interestingly, contemporaneous with the birth of the novel, if we accept this to be the writing of Don Quixote.

In the prologue Cervantes apologises for his lack of erudition: 'Now, my book must appear without all these advantages' - I read from Smollet's translation - 'for, I can neither quote in the margin, nor note in the end: nor do I know what authors I have imitated, that I may, like the rest of my brethren, prefix them to the work in alphabetical order'. ${ }^{13}$ The author's 'friend' gives him a useful tip, which Borges will adopt with imagination and verve: 'with regard to the practice of quoting ... for the embellishment of your history, you have nothing to do but to season the work with some Latin maxims, which your own memory will suggest, or a little industry in searching, easily obtain ...'14

The subsequent history of marginal commentary is too lengthy to be repeated here: some examples worth mentioning are Swift, exacting revenge on the critic Wooton, by incorporating his critical commentaries in the footnotes to the Tale in Tale of a Tub for obvious ridicule; Pope's satiric use of footnotes in the scribal persona of Scriblerus (in the Second Dunciad); Fielding's moralising digressions, addressing the reader directly to draw him/her in; Sterne, in Tristram Shandy, offering a counterpoint to the novel by drawing attention to it as a created literary product; Eliot, in The Waste Land, setting himself up as a critical annotator to his own poetry; though his notes do not clarify the poem but do what footnotes do: add another layer. Nabokov in Pale Fire (1962) does this more extravagantly. Pale Fire has been described as 'a sort of do-it-yourself detective story': four cantos or 69 pages of poetry (by a recently murdered poet, the fictional John Shade) are annotated posthumously by the 'Editor', the equally fictional Charles Kinbote, and a sinister plot suggests itself. Moving on to Latin America, a year later, Cortázar in Hopscotch, his highly experimental novel, had a whole section of what he called 'expendable' chapters, presented as footnotes to the mainline story, to be inserted at will, in a completely arbitrary fashion. Nø 62, on the chemical basis of all thought and emotions, was developed later into a full-length ludic novel, whose title, 62: A Model Kit, cannot be understood outside reference to the footnote. The footnotes to Manuel Puig's The Kiss of the Spider Woman are all (except for the invented last one) extracts taken straight from psychoanalytic and behaviourist theories on homosexuality, but rather than supporting the story of the homosexual

or origin, but affirms the play of interpretation' (p. 311). On Glas and footnoting, see J. Derrida, 'This is Not an Oral Footnote', in Stephen Barney (ed.) Annotation and its Texts, pp. 192-205.

13 Cervantes, Don Quixote, translated by Tobias Smollet (London: 1986), p. 22

14 Ibid., p. 23 
character they are meant to illustrate, they stand at odds, ironically, with it (I'm afraid this irony gets lost in the film). ${ }^{15}$

But where does Borges stand in all this?

The most quintessentially Borgesian precedent in the use of footnotes that I could find was a satirical text published in Basle, in 1776, by Gottlieb Wilhelm Rabener, entitled Hinkmars von Repkow Noten ohne Text. This work does away completely with the central text and consists wholly of footnotes. Rabener's straight-faced argument that if footnotes are a means of making money and achieving fame, why not 'cut out the middleman' as it were and write only footnotes without bothering with a text to tie them to. ${ }^{16}$ Even more Borgesian is what followed: now, I cannot vouch entirely for what I am about to say, my knowledge of German being too rudimentary to decipher the information available, but it appears that the fantasy was surpassed and a text produced that stood in for the missing corpus of the footnotes. I could have sought clarification of this point, but I resisted. The idea is so perfectly Borgesian that whether this book existed in reality or imagined as a Borgesian creation became somehow irrelevant.

The importance attached by Borges to glossa is hinted at in his well-known Credo such as set out in the Prologue to Fictions:

It is a laborious madness and an impoverishing one, the madness of composing vast books $\ldots$ better to pretend that those books already exist, and offer a summary, a commentary to them... A more reasonable, more inept, and more lazy man, I have chosen to write notes to imaginary books. ${ }^{17}$

This statement encourages us to view many of the stories themselves as extended footnotes. For example, 'The End' is a gloss on an episode from Hernández' Martin Fierro, and one can easily imagine Borges's story figuring as an annotation in future editions of this work. Similarly, future editions of Cervantes' Quixote could, in Part I, Chapter 9, carry a footnoted reference to a page from 'Pierre Menard, author of the Quixote' (to which I shall refer later), to say nothing of 'Three Versions of Judas' appearing in future New Testament commentaries.

I have chosen to focus exclusively on the footnotes in Borges's fiction. Surprisingly, or unsurprisingly perhaps, they are concentrated in the two collections generally regarded as 'the canonical texts', the ones that in the spirit of Tlön, seek 'to amaze, astound'. 18

15 For a fuller discussion of this topic, see Dan Balderson, 'Sexualidad y revolución: en torno a las notas de El beso de la mujer araña', El deseo, enorme cicatriz luminosa (Valencia, 1999), pp. 73-82.

16 Grafton (1997), p. 120.

17 Borges, 'Fictions', Collected Fictions, p. 67

18 'Tlön', p. 74. 
There are in all 17 stories with footnotes: seven in Fictions and eight in The Aleph. (This is the sort of useless information best relegated to the bottom of the page.) Some of the most brilliantly complex stories such as 'Death and the Compass' or 'Emma Zunz', or 'Funes, his Memory', are not footnoted, which makes it difficult, and in any case not desirable, to think of a neat, overarching theory to justify this study. The importance, as always for me in Borges, is in the particular, in the detail. What follows is a discussion of just a few footnotes, as part of a larger project.

'Tlön, Uqbar, Orbis Tertius' is the most richly annotated story, embellished, or disrupted, by six footnotes.

A brief reminder of its gist: concerned with a mysterious entry in an encyclopaedia regarding an unknown country (Uqbar) and its literature (Tlön), what is described in the story is a totally fictional world, a fantastic universe which is entirely logical and consistent with itself. (A true metaphor or conceit of idealism.) In a postscript, the mystery of the creation of Tlön and its description in a pirated encyclopaedia is explained, and it becomes clear that Tlön is not a metaphor of our universe but is different from it (its reverse) precisely because it is 'perfect' in its construction. And yet, from this ideal (in both senses), totally imagined universe, strangely hot and heavy objects, (hrönir) begin to invade our own real universe ...

As if to underline the subjective springboard that he claims for all his fiction ('they are all more or less autobiographical' Borges confessed when interviewed by Ronald Christ), ${ }^{19}$ Borges inscribes himself cryptically into this fantastic narrative through the use of his paternal grandmother's name, Haslam. In the text, Haslam, alias Borges, is the only traceable source of the apocryphal history of Uqbar, a sure give-away of the fabrication of his would-be learned disquisition. The reference to himself is doubly emphasised by the first footnote,

1 Haslam was also the author of A General History of Labyrinths.

This is clearly a wink to the reader and prophetic self-mocking allusion to the literary image with which he is so often identified. In fact, there is a network of these give-away self-inscriptions, camouflaged as markers of erudition adding scholarly credence to the text.

The second footnote,

2 Russell (The Analysis of Mind [1921], p. 159) posits that the world was created only moments ago, filled with human beings who 'remember' an illusory past.

links in all seriousness one of the schools of philosophy in Tlön to an idea pro-

19 The Narrow Act (New York, 1995), pp. 281-2. 
posed by Bertrand Russell in The Analysis of Mind, thereby suggesting wouldbe philosophical and scientific respectability for this pure fantasy based on a 'recollection' of a doubtful article in an encyclopaedia. But even this suggested respectability is undermined by the footnoted explanation, which questions the accuracy of memory. It should be read as a further invitation to view the whole recalled story with considerable scepticism: not only is the past illusory, but the ability of remembering it is queried by the use of inverted commas.

The third footnote,

3 A 'century', in keeping with the duodecimal system in use on Tlön, is a period of 144 years.

illustrates playfully the arbitrariness of all linguistic systems, warning us that even the one we regard as most natural, the numerical system, is but an arbitrary convention if one hundred years in one culture can mean 144 in another. A useful observation, today, for a postcolonial perspective. ${ }^{20}$

But the sting comes in the last footnote, mentioning as if in passing 'the problem of the material from which some objects are made'.

6 There is still, of course, the problem of the material from which some objects are made.

These are the hot and heavy 'objects' sent from the entirely ideal Tlön I mentioned before, and I see two coexisting, yet conflicting, readings: one, based on metaphor, would see these objects as embodiments, literally, material manifestations of the mind, illustrating the reification of ideas. A comment on the way in which ideas permeate our real world and acquire a presence in what we consider to be objective reality. The other, a more cynical and down-to-earth interpretation, shows that the real mystery, material objects arriving from an ideal universe, has actually not been addressed. This easily overlooked footnote in fact mocks the scholarly enterprise of footnoting, illustrating how under the disguise of academic respectability, the nub of a problem can be safely relegated to the bottom of the page and simply dismissed.

It shows us another side of footnotes, as 'safe refuge for untenable hypotheses'. ${ }^{21}$

20 I read footnote 4 (discussing the difference between 'identity' and 'equality') as a reductio ad absurdum of Plato's theory of celestial archetypes, and footnote 5, 'Buckley was a freethinker, a fatalist, and a defender of slavery,' as an example of Borges's throwaway use of dissonant association to complicate our picture of reality.

21 G.W. Bowersock, 'The Art of the Footnote', American Scholar, Winter 83/4, vol. 53, p. 61. 
This last footnote appears in a dubious postscript. Dated 1947 in 1940, it serves to confirm the 'fantastic' element of the story, although it presents itself as an illuminating 'factual' explanation of the mysteries. The impact of this play with time has been dulled over the years: the words 'So many things have happened since $1940 .$. . Allow me to recall some of them'22 had a more playful resonance in 1940. There are other post-dated postscripts such as the one to 'The Immortal', published in 1947 and dated 1950.23 But Borges keeps us on our toes: 'The Aleph', written and published in 1945, again has an explanatory postscript, but this time dated earlier, in 1943. (I shall return to this story.)

'The Approach to Al-Mu'tasim' is a review of a non-existent book of that name. So untutored in reading Borges were his contemporaries that some, even close friends of his, ordered the book from the London antiquarian who was reputed to have published it. Regarding the story's single, very long footnote (the longest of all), I wish to speculate on the fact that in annotating the last word of the story, 'that type of metempsychosis is called ibbur', the footnote suggests veiled parallels between this form of metempsychosis (where the soul of a living man is believed to enter the soul of another) and literary intertextuality.

1 In the course of this article, I have referred to the Mantiq al-Tair, or Conference [perhaps 'Parliament'] of the Birds, by the Persian mystic poet Farid aldin Abi Hamid Muhammad ben Ibrahim (known as Attar, or 'perfumer'), who was murdered by the soldiers under Tuluy, the son of Genghis Khan, when Nishapur was sacked. Perhaps I should summarise that poem. One of the splendid feathers of the distant King of the Birds, the Simurgh, falls into the centre of China; other birds, weary with the present state of anarchy, resolve to find this king ... They see that they are the Simurgh and that the Simurgh is each, and all, of them.

Also in the Enneads, we read:

The sun is all stars, and each star is all stars and the sun ...

And finally:

The Mantiq al-Tair has been translated into French by Garcin de Tassy, into English by Edward Fitzgerald; for this note I have consulted Richard Burton's 1001 Nights, vol. X, and Margaret Smith's study entitled The Persian Mystics: Attar (1932).

\section{Tlön, p. 78}

23 The postscript to 'The Immortal' has received excellent critical attention. See particularly Ronald Christ, The Narrow Act, pp. 227-44; and Djelal Kadir, Questing Fictions; Latin America's Family Romance (Minneapolis, 1986), pp. 67-9. Kadir's argument places a more serious focus on the Sábato footnote. 
The full footnote, and the trajectory of its argument is too long to delineate here, but in a nutshell, it addresses the main storyline, the quest that ends in self-discovery (in the novel, 'Approach to Al-Mu'tasim', and in the story of that title (the one we are reading) and in the Mantiq-al-Tair). Though also linked in the footnote to neoplatonism ('a paradisal extension of the principle of identity ... Anything is all things'), it shows how this topic has, through figurative metempsychosis, appeared in literature, at different times, in different guises (Garcin de Tassy's version, Fitzgerald's, The Arabian Nights, Margaret Smith's and now, Borges's).

Not quite the way intertextuality is usually presented by its most eloquent exponents (Kristeva, Bloom, Deleuze. Both metempsychosis and intertextuality are suggested obvious consequences of Neoplatonism.

'The Library of Babel' has been read earnestly, and not necessarily erroneously, as a metaphor for the universe, given its opening line: 'The universe (which others call the Library)' Borges, however, teasingly insists that the phantasmagoric description of the Library, with its self-multiplying hexagons, and dark, cramped cubicles is not fantasy but corresponds exactly to the miserable suburban library ('Miguel Cané') where he was working when he wrote the story. We may conjecture that it corresponded more to his unhappiness there. Remarking on how lowly his position was, and how obscure his incipient fame, he recalled the time when a fellow librarian came across an encyclopaedia entry on the author Jorge Luis Borges and was amused by the coincidence: 'funny that he should have the same name as you!'...

'The Library of Babel's sombre tones are attenuated by the subtle humour in the footnotes; I'll just mention the last where Borges gives the final word of judgement on the manuscript of an old and venerated librarian to a wellknown society lady, his friend Letizia Alvarez de Toledo, who summarily dismisses the library as useless: 'the vast library is pointless; strictly speaking, all that is required is a single volume. ... that would consist of an infinite number of infinitely thin pages ... each apparent page would open into other similar pages'. At the time of writing such a book seemed a flight of fantasy, a fantastic joke, a literary homage to the utopian livre infini, but its existence is becoming increasingly plausible: we recognise 'the total volume', as a perfect example of the hypertext; the Library, an anticipated description of the Web. ${ }^{24}$

The footnote in 'The Immortal' works on similar lines:

24 This single volume appears again as The Book of Sand in the story of that name. For a discussion of this footnote linked to Cavalieri's mathematical theory, see E. Ortiz 'The Transmission of Science from Europe to Argentina and its Impact on Literature: from Lugones to Borges', Borges and Europe Revisited, p.120. 
2 Ernesto Sábato suggests that the 'Giambattista' who discussed the origins of the Iliad with the rare book dealer Cartaphilus is Giambattista Vico, the Italian who defended the argument that Homer is a symbolic character, like Pluto or Achilles.

It too ascribes an insight to someone well known, this time to the respected writer Ernesto Sábato, with whom Borges had a less than cordial relationship. Borges was apparently displeased (to my mind rightly so, and I have written to this effect) by what he considered Sábato's reductive reading of his fiction; he could be wickedly vindictive and there may be some malice in the learned 'revelation' he attributes to Sábato in this footnote, for this is an idea that was readily ascertainable and therefore neither original nor particularly insightful.

Footnotes stand as intermediaries between author and reader; they are both inner and outer-directed and can either give clues to the understanding of the present text, or suggest alternative readings.

The single note to 'The House of Asterion' is a cryptic intimation of what will not be revealed until the end.

1 'The original reads 'fourteen', but there is more than enough cause to conclude that when spoken by Asterion that number stands for 'infinite'. ${ }^{25}$

It is a dry in-joke and an obscure give-away in that Borges often expressed the thought that the primitive mind cannot cope with numbers much beyond ten (fingers) and the gratuitous explanation that 'spoken by Asterion that number (fourteen) stands for infinity' hints that Asterion is not a person, but a primitive halfbeast. I view it as an aesthetic preparation for the final disclosure, that Asterion is the Minotaur.

'The Two Kings and the Two Labyrinths' (1952) is allegedly a gloss on the Borges story that immediately precedes it, 'Ibn-Hakam al-Bokhari, Murdered in his Labyrinth'. According to a footnote,

1 This is the story read by the rector from the pulpit. See p. 257'.

But instead of offering an explanation to 'Ibn-Hakam al-Bokhari, Murdered in his Labyrinth' it complicates it by opening it to further layers of interpretation. Borges himself adds to this complication by claiming that 'Ibn-Hakam', set out as the main text, is but a variation of its 'footnote', 'The Two Kings'. ${ }^{26}$

25 Presumably when not 'spoken by Asterion' fourteen may stand for infinity as a multiple of the mystical seven.

26 See the Afterword to the second edition of The Aleph (p. 288). The footnote to 'The Two Kings in their Two Labyrinths', and its reference in the Afterword are deliberately misleading in that this story had been published separately many years earlier, on 16 June 1939, in El Hogar as an Arabic Legend, and attributed to Sir Richard Burton, and in 1946, in Cuentos breves y extraodinarios. However, Borges did eventually admit to having written it. 
The footnote to 'The Theologians' acts as a synecdoche of the story. Concerned with the factional controversies between orthodox and heretics that divided the mediaeval Church, the ultimate irrelevance of their differences is suggested in the story's concluding lines. This cancelling of difference is foretold in the footnote, which draws attention to Runic crosses:

1 In Runic crosses the two enemy emblems co-exist intertwined.

These 'wheeled crosses' fusing Viking culture with Celtic Christianity are not, I think, to be read as a symbol of peaceful harmony, but as encapsulating the gist of the story (the insignificance of ideological controversies) in a graphic representation of its laconic ending: 'Aurelian discovered that in the eyes of the unfathomable deity, he and John of Pannonia (the orthodox and the heretic, the abominator and the abominated, the accuser and the victim) were a single person.'27

As is clear by now, footnotes add layers to a text. The following footnote, on the opening page of 'The Garden of Forking Paths', does so in a particularly relevant context. It puts into practice the utopian (if chaotic) novel posited in the story, one in which all possible outcomes are potentially pursued along 'eternally forking paths'.

${ }^{1}$ A bizarre and despicable supposition. The Prussian spy Hans Rabener, alias Viktor Runeberg, had turned an automatic pistol on his arresting officer, Capt. Richard Madden. Madden, in self-defence, inflicted the wounds on Rabener that caused his subsequent death. [ed. note.]

This footnote, of course, is an advance example of these forking paths, itself a suggestion of another narrative line in addition to those pursued in the main text. Linked to a historical topic, as is this story, the footnote also suggests not only the proliferation of alternative stories but alternative histories.

'Deutsches Requiem' is a much-maligned story written in lament not for the defeat of Germany as its title might suggest, but for its cultural self-mutilation through the destruction of what had been an important strand in its heritage, Judaism. The annotations are by an omniscient outside editor, giving this special insight to the first-person narrative.

The first,

1 It is significant that Zur Linde has omitted his most illustrious forebear, the theologian and Hebraist Johannes Forkel (1779-1846), who applied Hegel's dialectics to Christology and whose literal translation of some of the Apocrypha earned him the censure of Hengstenberg and the praise of Thilo and Gesenius.[Ed.]

27 'Los teologos', p. 207. 
tells us that the Nazi commander had suppressed a Hebraist ancestor from his family history, and can be read as a metaphor for Nazi Germany's suppression of its own Judaic heritage. The parallels between Nazi Germany and Zur Linde are all too clear. The idea that in causing the suicide of the highly symbolic Jewish poet David Jerusalem, the Nazi commander, emblematic of Germany, had killed part of himself is obliquely suggested by the information given in the following two footnotes, one which draws attention to the consequences of a wound,

3 It is rumoured that the wound had extremely serious consequences.[Ed.]

and the other underlining the similarities of the dates, 1 March 1939, when Zur Linde was wounded, and 1 March 1943, when David Jerusalem killed, or, as I suggest, sacrificed in self-immolation:

$5 \quad$ In neither the files nor the published work of Sorgel does Jerusalem's name appear. Nor does one find it in the histories of German literature. I do not, however, think that this is an invented figure. Many Jewish intellectuals were tortured in Tarnowitz on the orders of Otto Dietrich Zur Linde, among them the pianist Emma Rosenzweig. 'David Jerusalem' is perhaps a symbol for many individuals. We are told that he died on March 1, 1943; on March 1, 1939, the narrator had been wounded at Tilsit.[Ed.]

So far I have commented on footnotes that are an integral part of the stories, but the stories themselves are by now heavily footnoted, particularly with comments made by Borges in other contexts. 'The Immortal' is a case in point: by this I mean that Borges, as his own editor, has commented upon it critically as being too baroque, too luxurious, too sonorous, overweritten was the word he used, in English. He also made some suggestions as to how he might have rewritten it, which he didn't do. Taken as a footnote to the story, the commentary does that which interesting footnotes do, it makes us re-read this text, now in dialogue with the imagined new version.

'The Aleph', on the other hand, can be read in dialogue with the earlier four versions of the final manuscript, where alterations were scribbled, in differently coloured ink, in the margins, or on additional pages, thereby offering two or more simultaneous renditions of the story. From this palimpsestic reading of the annotated 'Aleph' we learn that Carlos Argentino Daneri was originally conceived as brother, not cousin to Beatriz, that his surname therefore was to have been Viterbo, (not Daneri), Argentino was originally Argentina and Daneri, D'Hastanghi (meaning from Hastings). The title changed from the Islamic Mihrab, (the focal point in a mosque) to Aleph. ${ }^{28}$

28 Information taken from a footnote to the story in Jean Bernès' magisterial two-volume critical edition, to which I referred earlier (p. 1602). 
An exhaustive study of this story based upon its manuscript by Julio Ortega is still awaited, but we know so far from him and from the story's dedicatee, Estela Canto, that Borges wrote the story in an exercise book, on squared paper and in a small handwriting. He used brackets to insert alternative terms for words he had crossed out.

As the manuscript of 'The Aleph' is not readily available, I shall offer a copy of a letter Borges wrote to Estela Canto at the time he was writing the story as an example of his 'insect-like handwriting'.

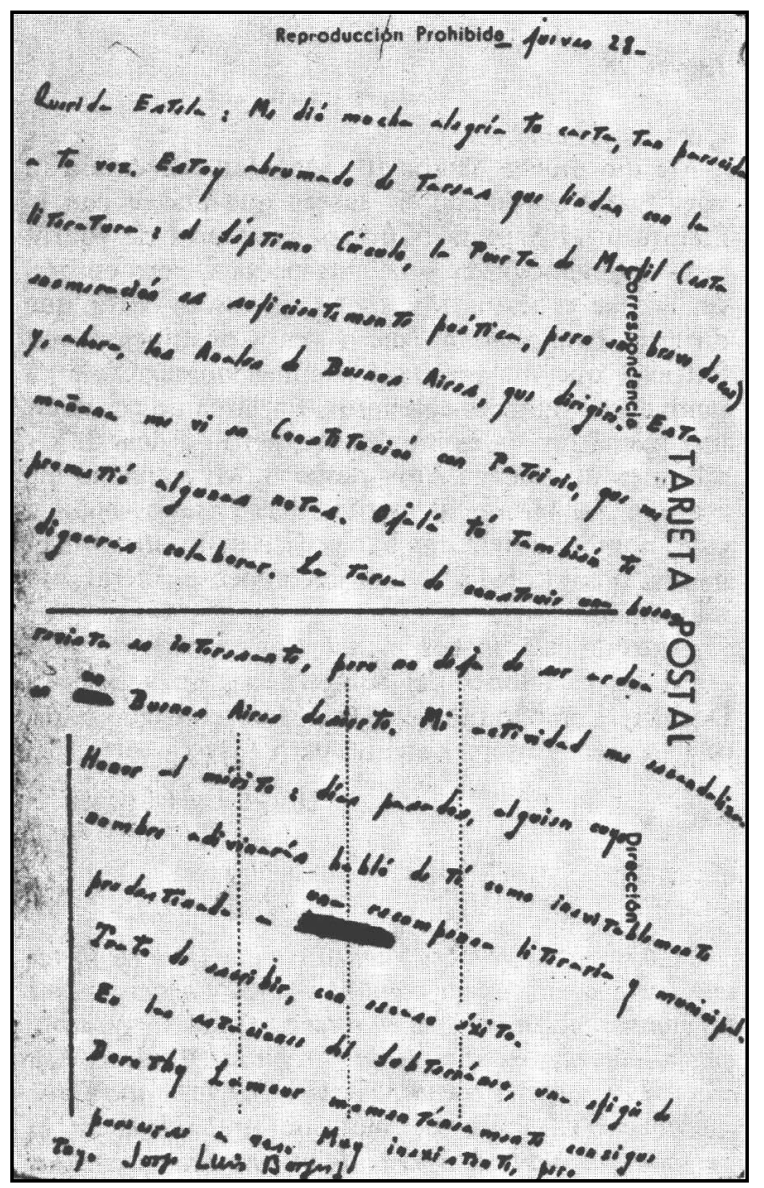

My point is to link this evidence of his handwriting to the final footnote in perhaps Borges's best known story, 'Pierre Menard, Author of Don Quixote', to argue that this is how Borges has self-mockingly inscribed himself as the pedantic Pierre Menard in the story of that name. There are, admittedly, other veiled indicators of this, which the footnote serves to confirm. 
I recall his square-ruled notebooks, his black crossings-out, his peculiar typographical symbols, and his insect-like handwriting. In the evening, he liked to go out for walks on the outskirts of Nîmes; he would often carry along a notebook and make a cheery bonfire (emphasis added).

'Pierre Menard, Author of Don Quixote': to think that there may be future generations of students deprived of feeling the frisson intended in this title! Will there be editions of this story with a footnote providing the information that the author of the Quixote was, in fact, Don Miguel de Cervantes? Certainly there are those who mistook the fictional Pierre Menard for a real author and annotated accordingly. ${ }^{29}$

'Pierre Menard' is the story that best exemplifies Borges's famous 'annotatory approach' - the term is Julio Ortega's - 30 in that it completely demolishes all absolutist notions of a finite text. It is too well known to warrant re-telling, but let me remind you very briefly of the great endeavour of the eponymous French symbolist poet: this is to re-write, rather, to write, the Quixote from his own vantage point. Like Cervantes before him, he writes the famous lines 'truth, whose mother is history, rival of time, depository of deeds, witness of the past, exemplar and adviser to the present, and the future's counsellor'. ${ }^{31}$

Although this new text coincides word for word with Cervantes's, if judged to be written by Pierre Menard (argues the narrator), in Nîmes, and in the twentieth century, its meaning is radically different. 'Truth, whose mother is history': what was mere rhetorical praise in the Spaniard's text has become a brazenly pragmatic proposition when written by a twentieth century author, for different ideas of 'truth' and 'history' prevail. Taken to logical conclusions, what this implies (and this is Menard's great legacy) is that every text offers infinite possibilities of interpretation, according to who the reader imagines the author to have been. A volume of Don Quixote on our library shelves could be by Cervantes, or by Pierre Menard, or by anyone else we choose to imagine. So too can any other book:

That technique, requiring infinite patience and concentration, encourages us to read the Odyssey as though it came after the Aeneid, to read Mme. Henri Bachelier's Le jardin du Centaure as though it were written by Mme. Henri Bachelier. ${ }^{32}$

The narrator clearly did not like poor Mme Henri Bachelier, whose novel was so obviously ghosted. (Can anyone imagine her writing anything?) In an

29 Pierre Menard features as a real author in a French PhD.

30 'Postmodernism in Latin America', Postmodern Fiction in Europe and the Americas, edited by T.

D'haen and H. Bertens (Antwerp, 1988), p. 195.

31 'Pierre Menard', p. 94.

32 Ibid., p. 95 
earlier footnote he explains for the sake of scholarly accuracy that Mme Bachelier had included in her list of Pierre Menard's oeuvre another work, but that this work had not been found, and concludes patronisingly that this was clearly a joke on the part of the poet:

1 'Mme. Henri Bachelier also lists a literal translation of Quevedo's literal translation of St. Francis de Sales's Introduction a la vie devote. In Pierre Menard's library there is no trace of such a work. This must be an instance of one of our friend's droll jokes, misheard or misunderstood.

But what is the mystery of the omitted book? Readers complicitous in the narrator's contempt for mature society ladies' literary insight have taken the footnote at face value. After all, it so seamlessly fits the stereotype of the femme savante ... But Borges is not a writer who deals in stereotypes: the joke, of course, is on the pompous narrator, and on his too trusting readers. For the lady about whom the narrator is so superiorly dismissive has understood what he, himself, clearly failed to do: that Menard not only (re-)wrote Cervantes's text, but re-wrote Quevedo's in the same way. The literal translation of Quevedo's literal translation is, of course, by Pierre Menard, and coexists in Quevedo's text.

This annotation turns the tables on the confident and arrogant narrator, but the cruelty of this unwitting self-exposure melts into laughter once we realise that the narrator, a mirror-image of the pedantically erudite Menard, is also a take-off of Borges himself. It stands as a self-mocking judgement of the absurd main storyline, but perhaps even more importantly, it stands as a self-mocking reference to the unrecognised limitations of our subjective, and prejudiced, understanding.

'Understanding' this footnote, when no other critic of Borges has either noticed or considered it worthy of comment, has served to highlight for me how much there is still to uncover, what hidden pleasures await readers of this livre infini.

I should like to conclude by considering briefly footnotes not in but to the work of Borges. By this I mean the way in which Borges has been used in the sense of a conventional footnote, that is, as supporting evidence conferring intellectual authority to another work. There are the almost obligatory references to Borges in the exposition of new ideas of literary theory such as made by Genette, in Palimpsestes, Foucault, most famously in Let mots et les choses, Derrida, in 'La Pharmacie de Platon'. Blanchot, Macherey, Bourdieu are just some of the names that could be added to this long list.

Modern fiction writers in whose work Borges's influence is clearly felt are legion: indeed Borges once claimed, in interview, that he had to change his style of writing because others were doing it so much better than he was. There is a website that gives numerous examples of these writers, but there is a Borgesian argument to be made, based on the essay 'Kafka and his Precursors' that this influence can be felt in all literature, past as well as present. I mentioned this web 
page to draw attention not to its contents but to the illustration that heads and glosses the list, a fantastic Hydra-headed creature sprouting human faces. This illustration is based on an original drawing by Borges. ${ }^{33}$ It may be understood as a humorous pictorial comment on the notion of 'creative misreading'.

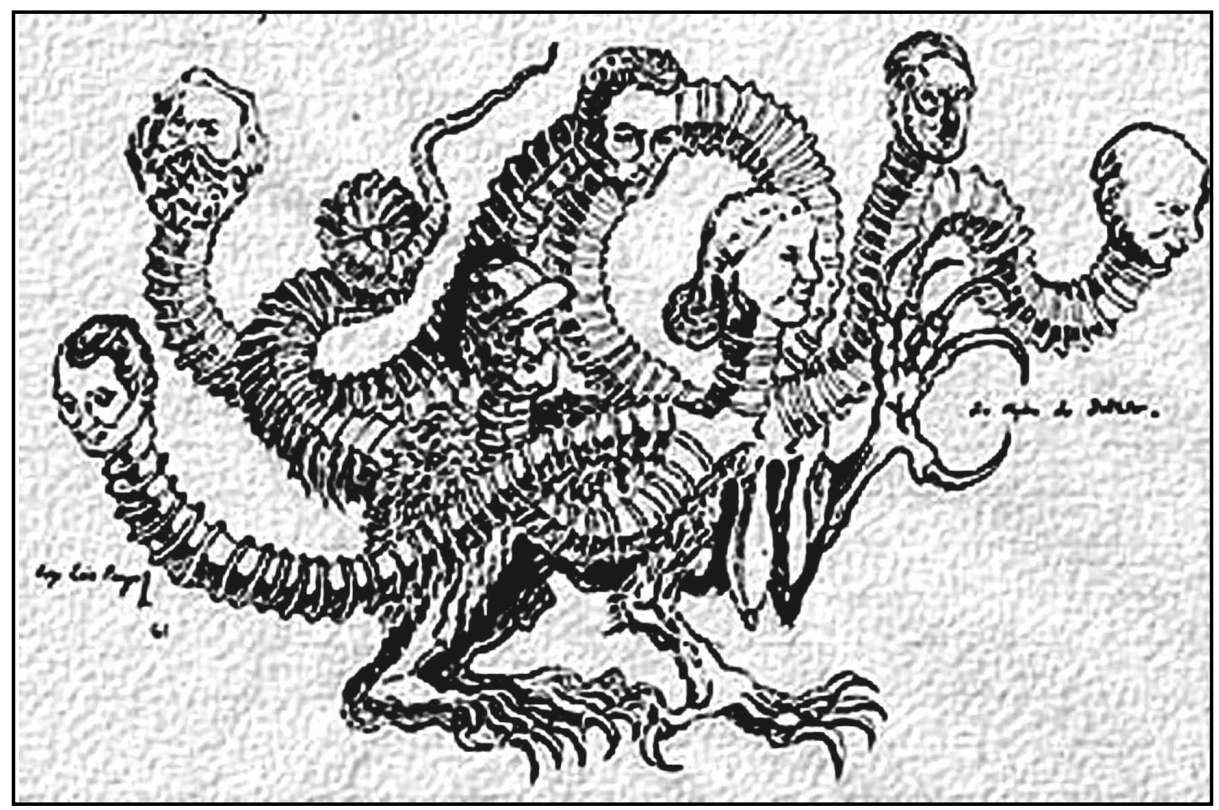

Another footnote to Borgesiana are the stories written specifically in tribute to him, particularly those in celebration of the centenary. Some are serious, others tongue-in-cheek parodies, others opportunistic exercises in self-advertisement. ${ }^{34}$

In a different class of footnotes are the misleading 'discoveries' of works by Borges, and their gullible reception. El nombre is a fake novel allegedly by Borges, whose spoof review appeared in a Spanish periodical. ${ }^{35}$ Another 'discovery', a poem entitled Instantes, has become something of a cause celèbre. When the Mexican writer Elena Poniatowska interviewed Borges, she read the poem to him as one of his, and Borges, who did not always hear and rarely listened, did not demur; this seemed to confirm his authorship as the conversation moved on to

33 Borges's original drawing is held in the University of Virginia's Special Collection.

34 As an example of a centenary homage, see Escrito sobre Borges. Catorce autores le rinden homenaje (Buenos Aires, 1999). This is compilation of re-writings of Borges stories by 14 Argentine writers, celebrating the Borgesian notion of the hypertext.

35 Siempre 31/1645 (2 January 1985). The review informs us that the novel has 215 pages and was published by Emecé in 1984 . 
other things. It was Maria Kodama who first expressed outrage that such an obviously clichéd work should have been ignorantly attributed to Borges. Many readers, including some notable academics, were taken in. But it is not the scandal that is interesting in this context but one of the incidents that ensued, and which would make a fitting posthumous footnote to 'The Theme of the Traitor and the Hero'. (This story tells of a foreseen political stratagem, the cover up of a hero's treason in order to help the cause he betrayed.) Fragments of the newly discovered poem were used without attribution by a Spanish Insurance Company on a TV advert; some incensed viewers wanted the company to be sued for plagiarising Borges, which was exactly the response the company had cynically anticipated as good publicity. The controversy as to whether the poem was, or was not, by Borges would only add to success of the publicity. 36

Borges wrote extensively on film and his influence in film criticism dates from the early 1960s when the adjective 'Borgesian' began to be persistently invoked in Cahiers du Cinéma and other film journals. ${ }^{37}$

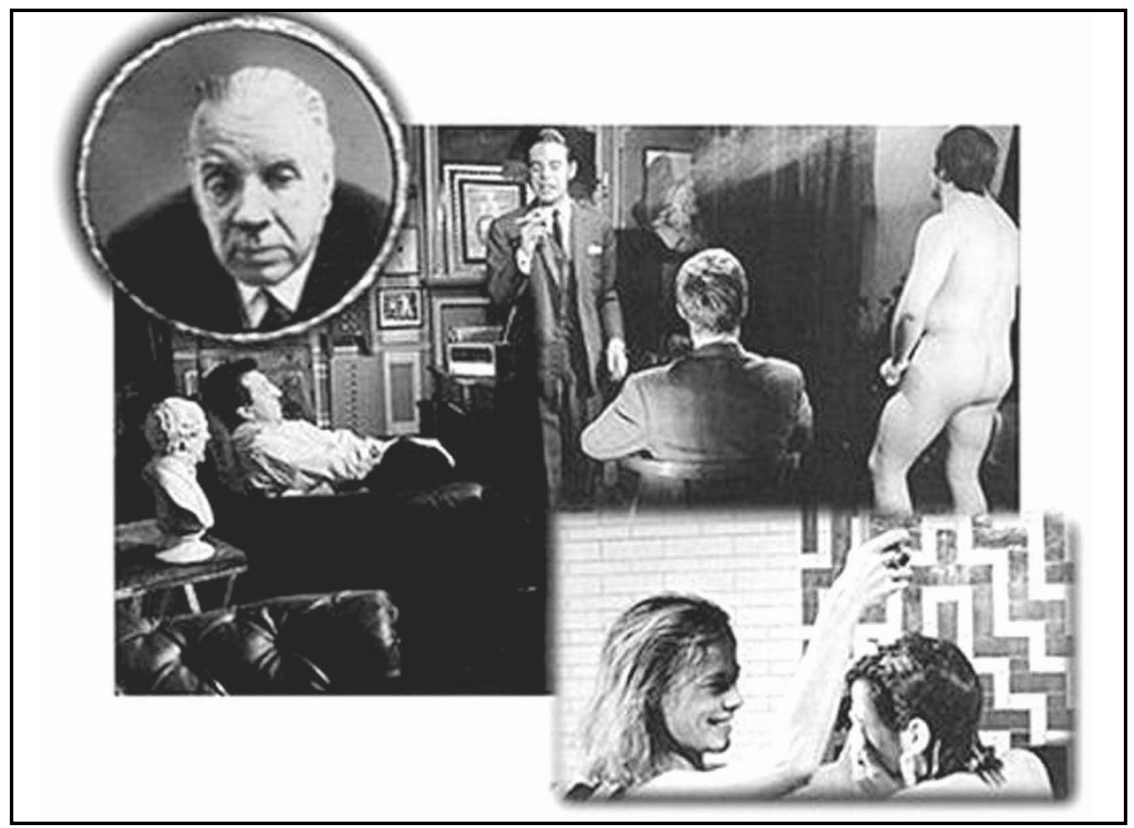

36 For a minutely recorded resume of this affair, see Ivan Almeida's witty article in Variaciones Borges, 10/2000, pp. 227-46. Alemeida points out the ultimate irony, that Borges should be 'defended' of plagiarism, which he had always considered a virtue (p. 239). Extensive ramifications of this extraordinary story of ongoing plagiarism can be searched on the Web under the title 'I'd pick more daisies'.

37 See Edgardo Cozarinsky, Borges in/and/on Film (New York, 1988), pp. 77-86. 
However, in Nicolas Roeg's famous 1970 film Performance, the references are on the screen itself: the bathroom where much goes on, including the reading aloud of unidentified extracts from a Borges story, ${ }^{38}$ is decorated with a labyrinthine motif, and the film's storyline follows several Borgesian themes such as a character's fatal encounter with his double, and the idea of a murder which might also be suicide. In tribute, Borges's (shattered) photograph appears at the end. The connection to Borges is highlighted in the above poster.

In music, several compositions were inspired by the works of Borges, from tango (Piazzola) to pop to contemporary 'classical' with titles such as 'Borges Fragments', 'Límites' (a Borges poem) and 'The Book of Imaginary Beings' (the revised title of his Manual de Zoología Fantástica).

In the visual arts, his work has inspired, among others, the Mexican painter Francisco Toledo, who produced magnificent illustrations to the abovementioned Manual de Zoología Fantástica.

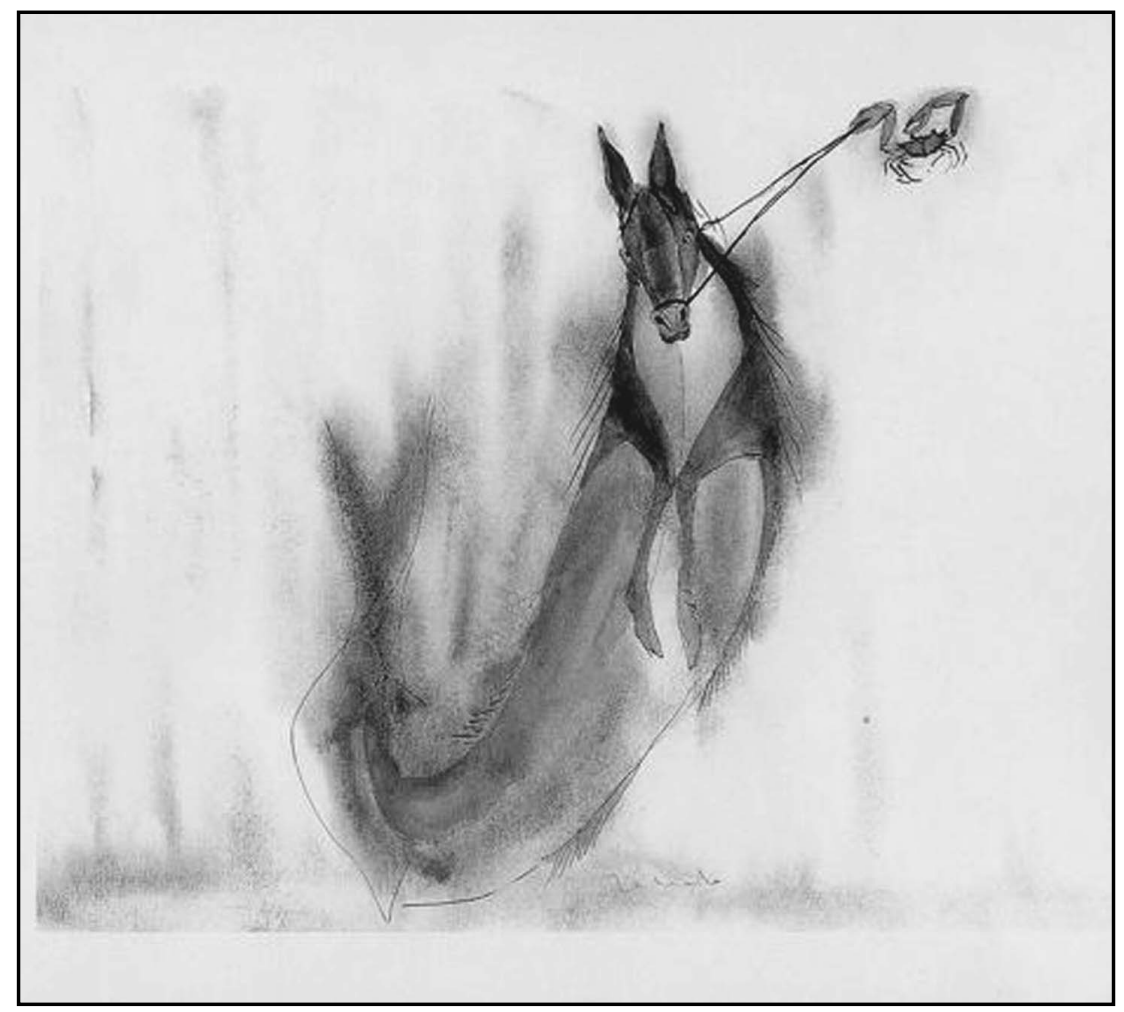

38 This is 'The South'. On Borges and Performance, see Cozarinsky, pp. 90-1. 


\section{Photography}

Sean Kernan's The Secret Books consists of 43 photographs inspired by Borges's writings. It exists in book form, or, with spectacular flash effects, on the Web. The artist confesses that his work 'doesn't attempt to illustrate Borges, and it doesn't aspire to be a collaboration — as an artist I couldn't hold his coat', but shows photographs that stand as parallel meditations to some Borges stories. 39

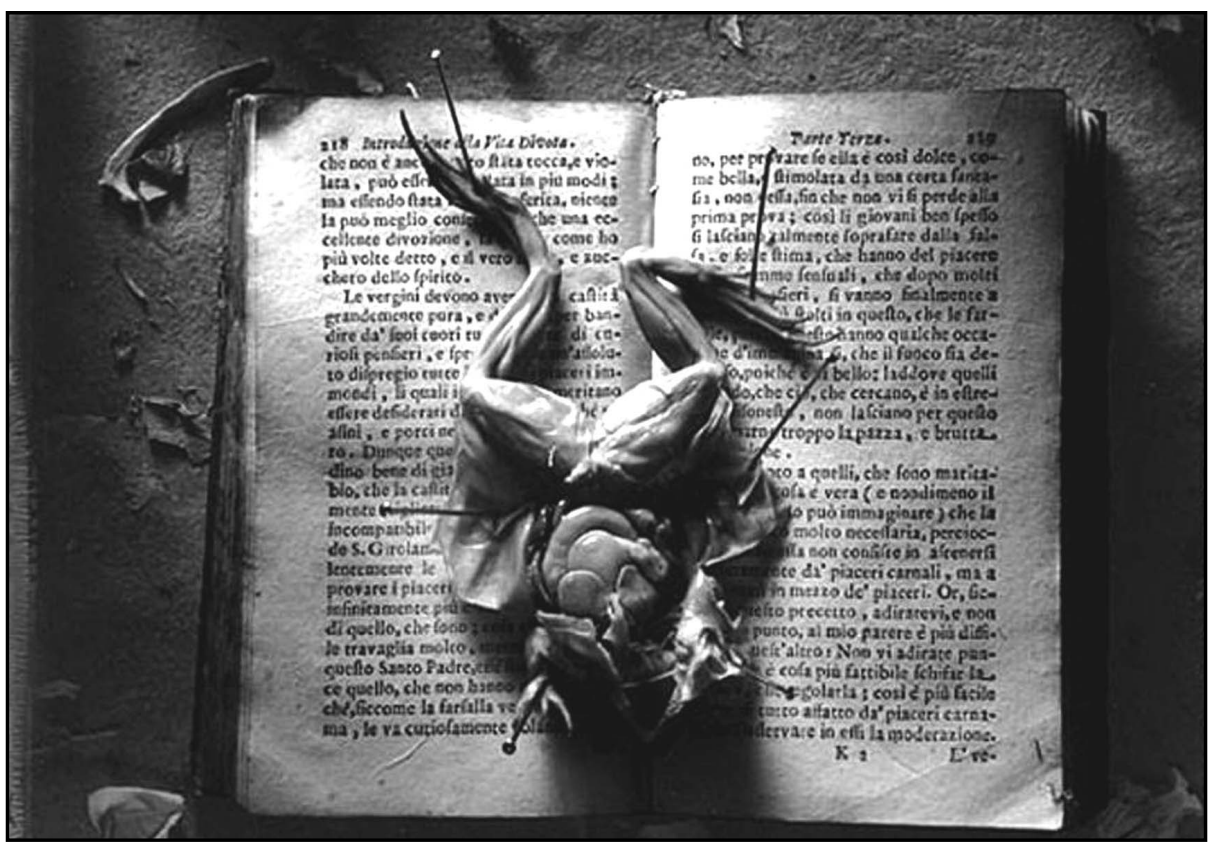

Information, news and e-mail discussions concerning Borges proliferate on the Web, in a veritable 'garden of forking paths' ${ }^{40}$ One last footnote: on one of the many sites on the Web devoted to entirely to 'Borgesiana' there is a small library whose virtual shelves are filled with books that Borges never wrote, but which figure in his stories and are here inventively summarised. On another we find the perfect example of hrönir in beautifully illustrated covers to these imagined books, which now have a firmer existence in our visual imaginary. ${ }^{41}$

39 In Kernan's words, he found inspiration in 'the joining of things that don't logically go together' and 'Borges's 'way of standing among the ordinary and pointing to possibilities that were unexpected and profound and alarming'.

40 This is the name of a now famous Borges website; others are the excellent 'Jorge Luis Borges Centre' and 'The Modern Word.com/Borges'.

41 The Vakalo School of Art and Design in Athens. 


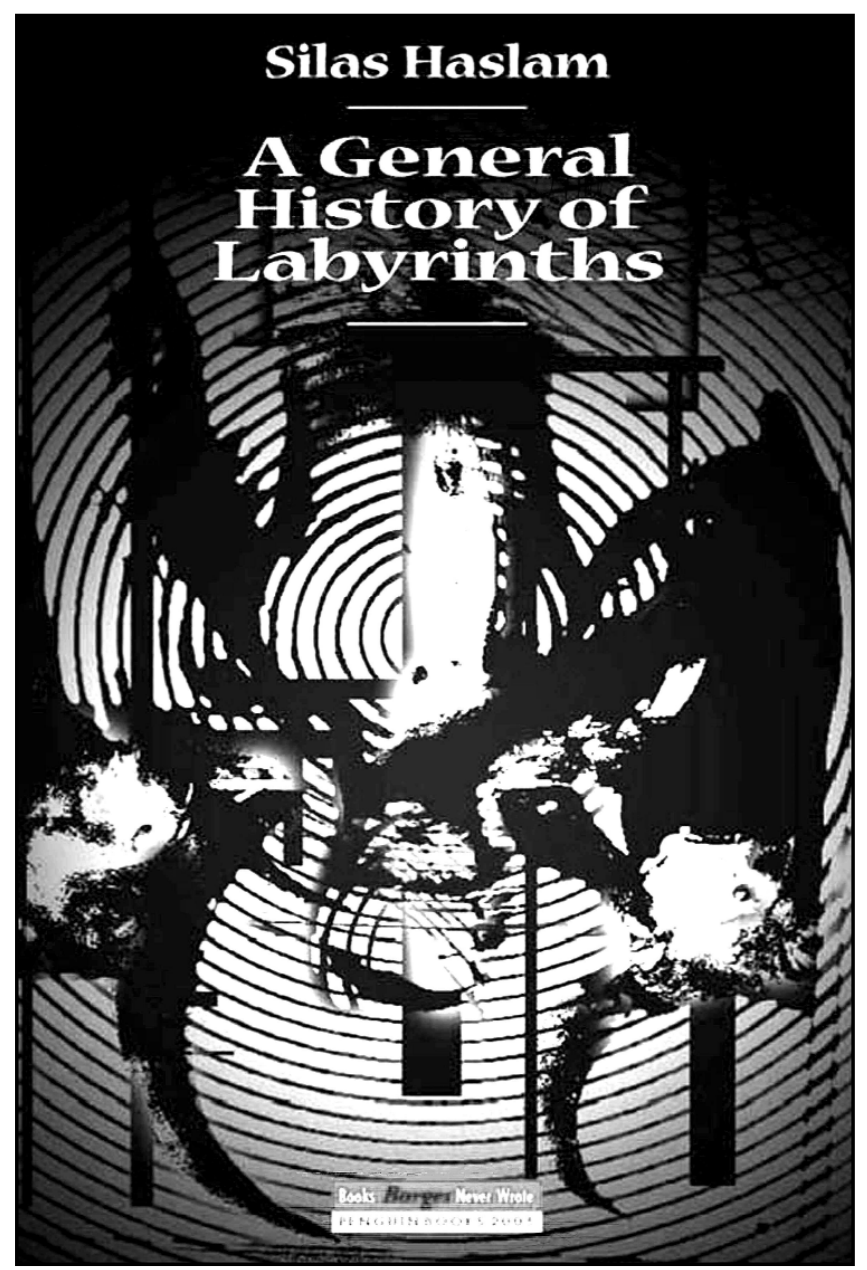

'And the world will be Tlön': 'And the world is Borges', as the Total Book continues to be written and sites continue to proliferate in cyberspace, each click of the mouse bringing to light a different 'footnote' to Borges studies.

Borges has permeated not only our thinking but our way of being in the world, in Uqbar, in Tlön and in Orbis Tertius. 
